\title{
Stres Kerja, Kompetensi, Kompensasi dan Pengaruhnya Terhadap Kinerja Karyawan dengan Motivasi Sebagai Variabel Intervening
}

\author{
Dian Pujiatma Vera Subchanifa ${ }^{1}$, Surepno ${ }^{2}$, Nugraheni Istiqomah ${ }^{3}$ \\ ${ }^{1}$ Sekolah Tinggi Agama Islam Pati, ${ }^{23}$ Institut Agama Islam Negeri Kudus \\ \surepno@iainkudus.ac.id
}

\begin{abstract}
: This study aims to obtain empirical evidence about the effect of work stress, competence, and compensation on employee performance with motivation as an intervening variable at KSPPS Fastabiq Khoiro Ummah Pati. The research method uses quantitative methods with the research sample of employees at KSPPS Fastabiq Khoiro Ummah Pati who have worked. minimum one year, amounting to 76 employees. The results showed that the work stress variable harmed employee performance. While the competency and compensation, variables have a positive and significant effect on employee performance. Job stress and competency variables do not affect employee performance which is mediated by work motivation. While the compensation variable affects employee performance mediated by work motivation.
\end{abstract}

Keywords : Job Stress, Competence, Compensation, Employee Performance, Motivation

\section{LATAR BELAKANG}

Kinerja karyawan adalah hasil dari unjuk kerja karyawan ketika melakukan pekerjaan. Kinerja merupakan catatan hasil yang diperoleh dari pekerjaan karyawan pada kurun waktu yang sudah ditetapkan (Fattah, 2017:8-9). Kinerja karyawan ialah hasil akhir karyawan ketika menyelesaikan tugasnya yang didukung dengan adanya kemampuan, arahan, dan tujuan.

Kinerja ialah hasil kerja seseorang ataupun kelompok orang pada sebuah organisasi, berdasarkan tanggung jawab tiap individu dalam meraih tujuan organisasi dengan cara legal, sesuai hukum, moral, maupun etika. Motivasi ialah dorongan, keinginan, serta tenaga penggerak dari diri sendiri agar melaksanakan suatu hal (Kristiani dan Pangastuti, 2019:2). Jika atasan memberikan motivasi kepada bawahan di dalam suatu organisasi, maka akan dapat berpengaruh tehadap kinerja karyawan.

Kinerja pegawai berperan penting untuk organisasi, jika kinerja pegawai rendah, membuat pencapaian tujuan organisasi terhambat. Kinerja ialah pencapaian hasil kerja pegawai dengan mengacu pada kualitas dan kuantitas selaku prestasi kerja pada kurun waktu yang sudah ditentukan, sesuai akan tugas serta tanggung jawab yang sudah diberikan. Banyak faktor yang mampu memberi pengaruh kinerja seseorang, salah satunya yakni motivasi kerja. Motivasi serta kinerja berhubungan erat serta keduanya saling berkaitan. Selain itu, banyak penelitian memperlihatkan bahwasanya motivasi yang baik dapat membuat kinerja yang baik pula (Rahim, dkk, 2017:134). 
Motivasi kerja ialah motor penggerak pada kinerja karyawan ketika menjalankan tugas pokok serta fungsinya pada organisasi perusahaan. Motivasi kerja sangatlah penting untuk karyawan, manajer ataupun para pemimpin dikarenakan melalui adanya motivasi yang tinggi, semua tugas dikerjakan secara semangat serta gairah yang menyebabkan hasil optimal dapat diraih dan dapat mendukung tujuan yang diinginkan tercapai secara efektif serta efisien. Motivasi seorang karyawan dalam bekerja pada umumnya dapat dilihat melalui aktivitas atau prilaku yang dilakukan secara berkelanjutan serta berfokus kepada tujuan.

Salah satu masalah penting untuk pimpinan pada sebuah organisasi yakni bagaimana memberi motivasi pada karyawan sehingga dapat meningkatkan kinerja karyawan. Motivasi haruslah diberikan dari pimpinan pada bawahannya dikarenakan terdapat dimensi pembagian pekerjaan, yang dimana bawahan bisa bersikap malas namun dengan memberi penghargaan serta kepuasan kerja dapat menghindari hal tersebut. Berkaitan dengan hal tersebut, pimpinan harus mampu menghadapi persoalan terkait cara menghadirkan situasi dimana bawahan mendapatkan kepuasan individu yang baik serta cara pimpinan memberikan motivasi pegawai supaya bekerja serta berprestasi (Ngatemin dan Arumwanti, 2012:82).

Motivasi secara signifikan memberi pengaruh pada kinerja karyawan. Pernyataan tesebut merupakan hasil penelitian Sutopo (2018). Hasil penelitian yang dilakukan Siswanto (2019) yaitu motivasi kerja dapat mempengaruhi kinerja karyawan. Putranto (2019) juga menemukan bahwasanya motivasi memberi pengaruh signifikan tehadap kinerja karyawan.

Perusahaan yang sudah berjalan sepatutnya memantau segala kegiatan operasionalnya. Dalam hal ini, pengendalian diterapkan agar dapat membantu memantau kegiatan-kegiatan perusahaan. Motivasi kerja karyawan dapat mengalami penurunan karena adanya kinerja dalam diri mereka menurun dan adanya peluangpeluang untuk melakukan kecurangan (Dewi, 2012:2). Sehingga, upaya-upaya meningkatkan motivasi dan kinerja karyawan yaitu dengan memperhatikan stres kerja, kompetensi, dan kompensasi karyawan.

Stres yang dirasakan individu yang berkaitan terhadap pekerjaanya merupakan stres kerja. Stres ialah kondisi ketika seseorang merasakan ketegangan dikarenakan terdapat kondisi-kondisi yang memberikan pengaruh pada dirinya, kondisi-kondisi terkait bisa didapatkan dari dalam atau luar diri seseorang. Banyak dimensi yang mengakibatkan terjadinya stres kerja. Stres yang melewati daya terima pegawai dapat membuat turunnya motivasi serta kinerja pegawai. Motivasi yang rendah secara langsung membuat kinerja pegawai kian turun (dan Sinambela, 2013:77). Stres kerja dapat terjadi apabila karyawan harus menyelesaikan tugas dari atasan yang tidak sesuai akan kemampuannya.

Penelitian oleh Siniaga \& Sinambela (2013) menemukan bahwasanya stres kerja memberi pengaruh signifikan pada motivasi dan kinerja auditor. Hasil penelitian yang dilakukan Martini dan Fadli (2010) mengatakan bahwa motivasi dipengaruhi oleh stres kerja. Naradhipa dan Azzuhri (2016) menyatakan stres kerja secara tak langsung memberi pengaruh signifikan pada kinerja karyawan melalui motivasi. Penelitian yang dilakukan Sutopo (2018) menjelaskan bahwa ada pengaruh negatif signifikan antar variabel stres kerja pada kinerja. Hasil penelitian tersebut tidak konsisten. Sehingga, peneliti berkeinginan meneliti stres kerja sebagai variabel yang memberi pengaruh motivasi dan stres kerja.

Variabel lainnya yang mampu memberi pengaruh motivasi serta kinerja karyawan yakni kompetensi karyawan. Kompetensi kerja ialah kemampuan kerja tiap 
individu yang berhubungan dengan kemampuan, keterampilan, pengetahuan, serta sikap kerja yang menyesuaikan ketentuan yang diterapkan (Sudaryo, dkk. 2018:7-8). Penyesuaian kompetensi karyawan dengan tugas yang telah ditentukan akan memberikan karyawan motivasi agar meningkatkan kinerjanya, yang membuat tugas yang diberikan akan terselesaikan dengan efektif serta efisien.

Motivasi dan kinerja karyawan dipengaruhi oleh kompetensi, hal tersebut dibuktikan melalui penelitian Poniman \& Saryanti (2017). Penelitian oleh Saputra dkk. (2016) menemukan terdapat pengaruh positif serta signifikan kompetensi pada kinerja karyawan. Kompetensi juga berpengaruh terhadap motivasi kerja yang selaras dengan penelitian Mulyati (2012). Penelitian Hidayanti (2018) menyatakan kompetensi memberi pengaruh negatif serta tak signifikan pada motivasi. Penelitianpenelitian tersebut meunjukkan hasil yang tidak konsisten. Sehingga, peneliti berkeinginan mengambil kompetensi selaku variabel independen.

Selain kompetensi, karyawan juga akan termotivasi jika mendapatkan kompensasi yang disesuaikan dengan kemampuan karyawan tesebut. Kompensasi adalah total imbalan dari perusahaan pada karyawan selaku tanda balas jasa (Sudaryo dkk., 2018:7). Tujuan utama kompensasi yakni sebagai sarana mempertahankan serta memotivasi karyawan untuk selalu meningkatkan kinerja.

Penelitian Gusmao \& Riana (2018) menemukan bahwasanya kompensasi memberikan pengaruh positif tak signifikan pada kinerja karyawan, sedangkan kompensasi memberikan pengaruh positif signifikan pada motivasi kerja karyawan. Kusuma (2017), dalam penelitiannya menemukan adanya pengaruh positif signifikan kompensasi pada motivasi dan kinerja karyawan. Pradita (2017) dalam penelitiannya menemukan kompensasi memberi pengaruh signifikan negatif pada penurunan motivasi dan kinerja karyawan. Merujuk pada hasil penelitian tersebut, terdapat perbedaan hasil penelitian dari peneliti terkait pengaruh kompensasi pada motivasi serta kinerja karyawan. Maka dari itu, peneliti akan membuktikan apakah kompensasi mampu mempengaruhi motivasi dan kinerja karyawan atau tidak.

KSPPS Fastabiq Koiro Ummah merupakan salah satu koperasi berbasis islami yang berkembang di Pati, Jawa Tengah. KSPPS ini mempunyai serangkaian standar kerja dan peraturan yang berlaku bagi semua karyawan, dan semua keryawan diwajibkan untuk mentaati dan mematuhi peraturan tersebut. Permasalahan yang dihadapi KSPPS Fastabiq Koiro Ummah adalah menurunnya motivasi kerja karyawan sehingga standar kinerja yang telah ditetapkan tidak tercapai.

Secara kuantitatif, indikasi terkait penurunan motivasi dan kinerja karyawan dapat dilihat melalui tingginya tingkat absensi karyawan KSPPS Fastabiq Khoiro Ummah dalam kurun waktu 12 bulan. Berdasarkan data perusahaan jumlah karyawan yang mangkir cukup tinggi yaitu 2-3\% per bulannya. Mengacu pada peraturan terkait hak cuti karyawan, karyawan yang tidak menyelesaikan tugas tanpa keterangan ataupun bukan tergolong hak cuti disebut mangkir atau absen. Absensi ataupun kemangkiran pada organisasi dianggap sebagai masalah dikarenakan dengan adanya kemangkiran akan menghambat penyelesaian pekerjaan dan penurunan kinerja (Dimyanti, 2011:88). 


\section{TEORI DAN METODE}

\subsection{Kinerja Karyawan}

Pengertian kinerja yakni hasil kerja secara kualitas serta kuantitas yang diraih karyawan berdasarkan tanggung jawab yang telah diberi. Kinerja merupakan perbandingan hasil yang diraih dan peran serta karyawan per satuan waktu, umumnya per jam. Kinerja juga diartikan selaku ungkapan seperti output, efisiensi dan efektivitas yang berhubungan degan produktivitas (Sulaksono, 2015:91).

Manajer dapat mengetahui apa saja yang sudah diraih serta apa saja yang belum dicapai oleh karyawan melalui penilaian kinerja karyawan. Penilaian kinerja bukanlah kegiatan kontrol ataupun kegiatan pengawasan serta bukan juga alat yang digunakan dalam mencari-cari kesalahan ketika menjatuhkan sanksi ataupun hukuman kepada karyawan yang bersangkutan. Penilaian kinerja terfokus kepada usaha untuk memperbaiki kesalahan ketika bekerja serta mengembangkan kelebihan karyawan guna tercapainya tujuan organisasi atau perusahaan (Muhammad, 2008:223-224).

Evaluasi kinerja adalah faktor utama agar perusahaan berkembang dengan efektif serta efisien, dikarenakan terdapat SDM yang lebih baik pada perusahaan tersebut. Evaluasi kinerja merupakan metode, proses evaluasi, serta pelaksanaan tugas seseorang, kelompok orang, unit-unit kinerja, ataupun tujuan yang telah ditetapkan terlebih dulu. Evaluasi kinerja adalah proses pengukuran kerja dari karyawan apakah bisa memberikan manfaat dalam meraih tujuan yang ada atau tidak (Rismawati dan Mattalata, 2018:5-6).

\subsection{Stres Kerja}

Stres adalah reaksi fisik dan psikologis terhadap peristiwa yang dipersepsi oleh seseorang sebagai sesuatu yang mengancam dirinya. Colman menyatakan definisi stres adalah tekanan fisiologis atau kondisi fisik, psikologis, ekonomi, sosial, dan emosional yang sulit untuk dikelola. Berdasarkan pada definisi stres, maka kemudian dapat dibuat definisi tentang stres kerja. Stres kerja (work stress) adalah reaksi fisik dan psikologis terhadap peristiwa yang dipersepsi oleh karyawan atau pekerja sebagai sesuatu yang mengancam dirinya dalam konteks pekerjaan atau jabatan (Hadi dan Hanurawan, 2018:55). Faktor penyebab stres kerja secara umum adalah tak ada dukungan sosial, tak ada kesempatan berperan dalam membuat keputusan di kantor, pelecehan seksual, kondisi lingkungan kerja, manajemen yang tak sehat, tipe kepribadian, dan tugas yang terlalu banyak (Margiati, 1999:72-73).

Terdapat dampak stres kerja yang memberikan keuntungan dan ada yang memberikan kerugian kepada perusahaan. Pengaruh yang memberikan keuntungan pada perusahaan diharapkan mampu memberikan acuan pada karyawan agar menyelesaikan tugas yang telah diberikan secara maksimal. Reaksi terkait stres kerja dapat memiliki sifat psikis atau fisik. Perubahan perilaku dari karyawan memperlihatkan bahwa karyawan tersebut mengalami stres kerja. Menurut Lubis, stres kerja dapat berdampak sebagai berikut:

1. Stres kerja fisik. Akibat stres kerja fisik dapat dikenali dengan mudah. Terdapat beberapa penyakit dikarenakan karyawan merasa stres yang cukup tinggi serta dapat berkepanjangan, yaitu penyakit jantung, bisul, tekanan darah tinggi, serta sakit kepala.

2. Stres kerja psikologis. Dampak stres pada aspek psikis dapat dilihat pada adanya ketidakpuasan dalam bekerja, depresi, mudah letih, murung, serta kurang bersemangat (Vanchapo, 2019:49-50).

Ada dua jenis penyelesaian (coping) stres kerja, yanitu: 
1. Copping yang berfokus pada masalah (problemsolving focused):
a. Confrontive coping: berpegang teguh akan pendiriannya serta memperjuangkan apa yang diingin.
b. Seeking support coping: mengatasi situasi stres dengan cara mencari bantuan dan dukungan dari orang lain.
c. Planful problem solving: menyusun rencana tindakan serta megubah situasi dalam pemecahan masalah yang tengah dihadapi.

2. Copping yang terfokus kepada emosi (emotion focused coping), yakni usaha dalam menurunkan emosi negatif yang dirasa saat tengah menghadapi masalah ataupun tekanan. Emotion focused coping diantaranya:
a. Self control: mengatur perasaan serta tindakan. Contohnya, individu mulai mengidentifikasi tindakan baik dan buruk.
b. Distancing: meyibukkan diri dengan melakukan berbagai aktivitas positif. Contohnya, megikuti organisasi dan olahraga.
c. Positive reappraisal: mengubah pemikiran diri secara positif yang memiliki nilai religius. Misalnya, melalui bersyukur (gratitude), seseorang akan disentuh aspek kognisinya (cara bepikir), emosi (berempati) secara spiritual (keyakinan).
d. Accepting responssbility: menjadikan kesalahan sebagai sarana pembelajaran dan dijadikan sebagai pengalaman. Contohnya, seorang teller bank yang pernah melakukan kesalahan dalam menghitung, ia belajar untuk mengatasinya degan lebih teliti.
e. Escapeavoidance: menghindari ataupun melarikan diri dari lingkungan secara nyata. Contohnya, keluar dari tempat kerja (resign) (Eko Wahyu Cahyono, 2019:11).

\subsection{Kompetensi}

Kompetensi merupakan karakteristik yang memiliki kaitan akan efektivitas kinerja individu ketika melakukan pekerjaan ataupun karakteristik dasar berhubungan dengan kasual ataupun selaku sebab-akibat dengan kriteria yang menjadi acuan, berkinerja dengan efektif di tempat kerja ataupun di situasi tetentu. Kompetensi merupakan kemampuan individu dalam melaksanakan suatu hal selaku hasil dari proses belajar. Dalam pegertian lain, kompetensi merupakan pengetahuan, keterampilan, serta kemampuan seseorang untuk menyelesaikan tugasnya secara kognitif, efektif, dan psikomotorik dengan sebaik-baiknya (Pianda, 2018:30-31).

Sartifikasi kompetensi kerja merupakan proses memberikan sertifikat kompetensi dengan sistematis serta obyektif dengan uji kompetensi berdasarkan Standar Kompetensi Kerja Nasional, Standar Nasional \& Standar Khusus. Tujuan diberikannya sertifikat tersebut yakni memberi pengakuan serta penghargaan kompetensi. Guna mencapai tujuan penjaminan serta pemeliharaan mutu kompetensi, prinsip-prinsip dilaksanakannya sertifikasi kompetensi profesi adalah keterukuran, obyektivitas, ketelusuran, dan akuntabilitas (Malik, 2016:160-161).

Kompetensi memiliki lima tipe, yaitu:

1. Motives adalah keingingan secara konsisten yang dapat menimbulkan tindakan untuk mencapai keinginan tesebut.

2. Traits yakni karakteristik fisik serta respon-respon konsisten pada keadaan tetentu.

3. Self Concept yakni konsep individu itu sendiri sehingga mampu efektif pada segala situasi. 
4. Pengetahuan. Kategori ini berkaitan dengan informasi milik karyawan terhadap suatu bidang tertentu.

5. Keterampilan yakni kemampuan individu dalam melaksanakan tugas fisik ataupun mental (Prihadi, 2004:92-94).

\subsection{Kompensasi}

Ivancevich dalam Kadarisman mengemukakan kompensasi sebagai fungsi Human Resource Management (HRM) yang berkaitan akan tiap reward yang didapatkan individu selaku balasan terhadap pelaksanaan tugas-tugas organisasi. Pegawai menukarkan tenaganya agar mendapat reward finansial atau nonfinansial (Kadarisman, 2012:6). Kompensasi (compensation) merupakan pemberian balas jasa langsung (direct) serta tak langsung (indirect), uang ataupun barang pada karyawan selaku imbalan jasa dari perusahaan. Prinsip kompensasi yakni adil serta layak. Adil bermakna sesuai akan prestasi kerjanya, layak bermakna terpenuhinya kebutuhan primer dan mengacu kepada batas upah minimum pemerintah serta mengacu pada internal serta eksternal konsistensi (Hasibuan, 2010:22).

Tujuan diberikannya kompensasi yakni:

1. Memenuhi kebutuhan ekonomi. Melalui kepastian mendapatkan upah atau gaji secara periodik, bermakna adanya jaminan "economic security" bagi karyawan itu sendiri serta keluarganya.

2. Mengembangkan produktivitas kerja. Memberikan kompensasi yang kian baik, maka pekerja tersebut akan semakin produktif dalam bekerja.

3. Memajukan organisasi ataupun perusahaan. Kian tinggi perusahaan ataupun organisasi dalam memberi kompensasi, maka perusahaan tersebut akan kian sukses. Karena, perusahaan memberikan kompensasi yang tinggi disebabkan oleh pendapatan perusahaan yang kian besar pula.

4. Menciptakan keseimbangan serta keadilan. Memberikan kompensasi berkaitan akan tanggung jawab pekerja atas jabatannya sehingga menciptakan keseimbangan antar input serta output (Marnisah, 2012:114-115).

Program kompensasi (balas jasa) haruslah ditetapkan berdasarkan asas adil, layak serta mengacu pada UU Perburuhan yang ada.

1. Asas Adil

Besaran kompensasi yang dibayarkan pada tiap karyawan haruslah menyesuaikan akan prestasi kerja, jenis pekerjaan, risiko pekerjaan, tanggung jawab, serta jabatan pekarja. Sehingga, adil bukan bermakna tiap karyawan mendapatkan kompensasi yang memiliki besaran serupa. Namun, asas adil haruslah menjadi dasar penilaian, perlakuan, serta memberi hadiah ataupun hukuman untuk tiap karyawan. Dengan asas adil dapat menciptakan suasana kerja sama yang baik, semangat kerja, disiplin, loyalitas, serta stabilisasi karyawan dapat lebih baik.

2. Asas Layak dan Wajar

Kompensasi yang didapatkan karyawan mampu memenuhi kebutuhannya pada tingkatan normatif yang ideal. Tolak ukur layak ialah relatif, penentuan besaran kompensasi didasari pada batasan upah minimum pemerintah serta eksternal konsistensi yang ada (Hasibuan, 2010:122-123). 
Jenis kompensasi dikategorikan menjadi:

1. Kompensasi Langsung

Kompensasi langsung ialah kompensasi yang diberikan secara langsung yang dapat berbentuk gaji, insentif, serta upah. Pengertian gaji yakni balas jasa yang kepada karyawan karena sudah memberi tenaga serta pikiran dalam meraih tujuan perusahaan. Upah ialah kompensasi yang diberikan kepada karyawan yang didasari pada jam kerja, jumlah barang yang dihasilkan, atau dari banyaknya pelayanan yang ada. Insentif merupakan kompensasi yang diterima oleh karyawan tertentu atas prestasi yang telah dicapai (Elbadiansyah, 2017, 213).

2. Kompensasi Tak Langsung

Kompensasi tak langsung ialah kompensasi yang secara tak langsung dirasa karyawan yang dapat berbentuk benefit, tunjangan, fasilitas kesehatan, transportasi, serta lain-lain. Kompensasi tak langsung disebut juga kompensasi pelengkap. Kompensasi jenis ini diberi ke karyawan yang tujuannya melengkapi kompensasi dari perusahaan (Sutrisno, 2017:184).

\subsection{Motivasi Kerja}

Kata motivasi memiliki asal kata motif (motive) yang bermakna dorongan, sebab ataupun alasan seseorang dalam melakukan suatu hal. Motivasi berakar dari bahasa latin yaitu "movere" yang bermakna dorongan ataupun menggerakkan. Secara etimologi, motivasi memiliki kaitan akan hal-hal yang mendorong ataupun menggerakkan seseorang dalam melakukan sesuatu.

Secara umum, motivasi merupakan alat serta cara membangkitkan minat ataupun keinginan dalam melaksanakan suatu hal yang dirasa memberikan manfaat untuk seseorang itu sendiri ataupun bagi orang lain. Motivasi juga merupakan tenaga pendorong ataupun penarik tingkah laku ke arah tujuan tertentu. Tingkah laku ataupun tindakan seseorang dapat muncul apabila terdapat sesuatu yang dapat mendorong seseorang untuk berbuat serta bertingkah laku agar meraih suatu tujuan (Mohtar, 2019:19).

\subsection{Metode Penelitian}

Berdasarkan sumber data ataupun informasi yang didapatkan, adapun jenis penelitian ini yakni penelitian lapangan (field research). Penelitian lapangan ialah penelitian bersasaran penelitian masyarakat, baik masyarakat umum atau khusus (Syatori dan Ghozali, 2012:55). Penelitian ini memiliki tujuan mengevaluasi pengaruh stres kerja, kompetensi, dan kompensasi pada motivasi serta kinerja karyawan di KSPPS Fastabiq Khoiro Ummah.

Pendekatan penelitiannya yakni menggunakan pendekatan kuantitatif. Pendekatan ini lebih berfokus kepada uji teori-teori dengan pengukuran variabel penelitian melalui angka serta menganalisis data melalui prosedur statistik. Penelitianpenelitian yang menggunakan pendekatan deduktif dengan tujuan uji hipotesis adalah contoh tipe penelitian yang mengaplikasikan paradigma kuantitatif (penelitian kuantitatif) (Sugiyono, 2015,402).

Penelitian ini menggunakan pendekatan kuantitatif asosiatif, dikarenakan bertujuan untuk mengetahui hubungan atau Pengaruh dua variabel ataupun lebih yang digunakan untuk meneliti sumber masalah penelitian. Pengumpulan data primer dilaksanakan degan menyebarkan kuesioner yang diberikan langsung kepada responden. 
Populasi pada penelitian ini adalah seluruh karyawan KSPPS Fastabiq Khaira Ummah yang berjumlah 189 karyawan. Kemudian sampel penelitian ini menggunakan purposive sampling dengan kriteria sudah bekerja minimal 1 tahun yaitu sebanyak 76 karyawan.

\subsection{Hipotesis}

Hipotesis merupakan jawaban permasalahan sementara yang memiliki sifat dugaan dari suatu penelitian. Dugaan tersebut haruslah terbukti kebenarannya melalui data empiris (fakta lapangan). Hipotesis dapat terbukti ataupun sebaliknya serta didukung oleh fakta-fakta hasil penelitian lapangan (Supardi, 2005:69). Hipotesis dalam penelitian ini adalah sebagai berikut:

H1: Stres kerja berpengaruh terhadap kinerja karyawan karyawan

H2: Kompetensi berpengaruh terhadap kinerja karyawan

H3: Kompensasi berpengaruh terhadap kinerja kinerja karyawan

H4: Motivasi mempunyai pengaruh intervening dalam pengaruh stres kerja terhadap kinerja karyawan

H5: Motivasi mempunyai pengaruh intervening dalam pengaruh kompetensi terhadap kinerja karyawan

H6: Motivasi memberi pengaruh intervening dalam pengaruh kompensasi terhadap kinerja karyawan

\section{HASIL DAN PEMBAHASAN}

\subsection{Hasil Analisis Data}

Berdasarkan hasil perhitungan statistik yang dilakukan oleh peneliti, maka hipotesis pertama yang diajukan (H1) yakni stres kerja (X1) memberi pengaruh pada kinerja karyawan di KSPPS Fastabiq Khoiro Ummah Pati, ditolak karena nilai t hitung 1,489 serta t tabel 1,993 bermakna nilai t hitung $<\mathrm{t}$ tabel $(1,489<1,993)$ dengan $p$ value (sig) 0,141 (>0,05). Sehingga, variabel stres kerja tidak memberi pengaruh pada kinerja karyawan di KSPPS Fastabiq Khoiro Ummah.

Hipotesis kedua (H2) yakni kompetensi (X2) memberi pengaruh pada kinerja karyawan di KSPPS Fastabiq Khoiro Ummah Pati, diterima karena nilai t hitung 2,316 serta $t$ tabel 1,993, bermakan nilai $t>t$ tabel $(2,316>1,993)$ dengan $p$ value (sig) 0,023 $(<0,05)$. Sehingga, variabel kompetensi memberi pengaruh pada kinerja karyawan di KSPPS Fastabiq Khoiro Ummah. Hipotesis ketiga (H3) yakni kompensasi (X3) memberi pengaruh pada kinerja karyawan di KSPPS Fastabiq Khoiro Ummah, diterima karena nilai t hitung 2,728 serta t tabel 1,993 bermakna nilai t hitung $>t$ tabel $(2,728>1,993)$ dengan $p$ value (sig) 0,008 $(<0,05)$. Sehingga, variabel kompensasi memberi pengaruh pada kinerja karyawan di KSPPS Fastabiq Khoiro Ummah.

Hipotesis keempat (H4) yakni motivasi (Y) mempunyai pengaruh intervening dalam pengaruh stres kerja (X1) terhadap kinerja, ditolak karena nilai thitung $=1,5375$ $<\mathrm{t}$ tabel 1,993, maka tak terdapat pengaruh mediasi. Hipotesis kelima (H5) yakni motivasi (Y) mempunyai pengaruh intervening dalam pengaruh kompetensi (X2) terhadap kinerja, ditolak karena nilai t hitung $=1,72<\mathrm{t}$ tabel 1,993, maka tak terdapat pengaruh mediasi.

Hipotesis keenam (H6) yakni motivasi (Z) memberi pengaruh intervening dalam pengaruh kompensasi (X3) terhadap kinerja, diterima karena nilai t hitung = 2,275 > t tabel 1,993, maka terdapat pengaruh mediasi. Dari uji F didapatkan Fhitung 
83,285 dengan tingkat signifikansi 0,000 $<0,05$ dikarenakan $\mathrm{F}$ hitung $>\mathrm{F}$ tabel $(83,285$ $>$ 4,627), maka H0 ditolak serta Ha diterima, artinya stres kerja, kompetensi, kompensasi, dan motivasi secara bersamaan memberi pengaruh pada kinerja karyawan di KSPPS Fastabiq Khoiro Ummah. Adapun nilai Adjusted $R$ Square $=0,814$, bermakna 81,4\% variabel kinerja dapat dijelaskan oleh variasi dari 4 variabel yakni stres kerja, kompetensi, kompensasi, serta motivasi. Lalu sisanya $(100 \%-81,4 \%)$, $18,6 \%$ dijelaskan oleh variabel lainnya di luar model.

\subsection{Pembahasan}

Variabel stres kerja tidak memberi pengaruh pada kinerja karyawan di KSPPS Fastabiq Khoiro Ummah Pati. Hal ini dikarenakan bahwa stres kerja tergantung pada individu masing-masing dalam menghadapi masalah. Karyawan saat menghadapi masalah justru tertantang untuk mencapai target sehingga individu tidak merasa stres.

Variabel kompetensi berpengaruh positif serta signifikan pada kinerja karyawan di KSPPS Fastabiq Khoiro Ummah Pati. Hal tersebut dikarenakan semakin baik kompetensi yang dimiliki karyawan dengan kemampuan melakukan suatu pekerjaan yang dilandasi dengan keterampilan dan pengetahuan serta didukung oleh sikap kerja, maka kinerja karyawan juga semakin baik.

Variabel kompensasi berpengaruh positif serta signifikan pada kinerja karyawan di KSPPS Fastabiq Khoiro Ummah Pati. Semakin besar atau meningkat kompensasi yang diberikan karyawan, maka semakin besar pula kinerja karyawan. Hal ini sesuai degan teori kompensasi menurut Ivancevich sebagaimana dikutip oleh Kadarisman bahwa kompensasi adalah fungsi Human Resource Management (HRM) yang berhubungan dengan setiap jenis reward yang diterima individu sebagai balasan atas pelaksanaan tugas-tugas organisasi.

Stres kerja tak memberi pengaruh pada kinerja karyawan yang dimediasi motivasi kerja di KSPPS Fastabiq Khoiro Ummah Pati. Hal ini dikarenakan perusahaan mengelola stres kerja dengan baik sehingga tidak mempengaruhi motivasi, dan karyawan tetap menyelesaikan tugas yang diberikan dengan efektif dan efisien.

Kompetensi tidak memberi pengaruh pada kinerja karyawan yang dimediasi motivasi kerja di KSPPS Fastabiq Khoiro Ummah Pati. Hal ini dikarenakan perusahaan tidak ikut serta mendukung peningkatan kompetensi karyawan meskipun karyawan memiliki pengetahuan, kemampuan, pemahaman, dan sikap yang baik.

Kompensasi memberi pengaruh pada kinerja karyawan yang dimediasi motivasi kerja di KSPPS Fastabiq Khoiro Ummah Pati. Hal tersebut dikarenakan diberikannya bonus dan insentif dari atasan dan pembarian fasilitas yang memadai sehingga membuat karyawan termotivasi untuk meningkatkan kinerjanya.

\section{PENUTUP}

Hasil penelitian menunjukkan bahwa variabel stres kerja berpengaruh negatif terhadap kinerja karyawan. Sedangkan variabel kompetensi dan kompensasi berpengaruh positif dan signifikan terhadap kinerja karyawan. Variabel stres kerja dan kompetensi tidak berpengaruh terhadap kinerja karyawan yang dimediasi oleh variable motivasi kerja. Sedangkan variabel kompensasi berpengaruh terhadap kinerja karyawan yang dimediasi motivasi kerja.

Saran untuk penelitian selanjutnya adalah dengan menambah variabel independen lain agar tingkat signifikasi pengaruhnya lebih besar. KSPPS Fastabiq Khoiro Ummah hendaknya meminimalisir stres kerja karyawan, meningkatkan kompetensi karyawan, serta memberikan kompensasi yang tepat sesuai dengan 
keahlian agar dapat meningkatkan motivasi karyawan dalam bekerja yang pada akhirnya dapat meningkatkan kinerja. 


\section{DAFTAR PUSTAKA}

Busro, Muhammad. Teori-teori Manajemen Sumber Daya Manusia. Jakarta: Prenadamedia Group, 2018.

Cahyono, Eko Wahyu. The Power Of Gratitude. Yogyakarta: Deepublish, 2019.

Elbadiansyah. Manajemen Sumber Daya Manusia. Malang: CV. IRDH, 2017.

Fattah, Husein. Kepuasan Kerja dan Kinerja Pegawai. Yogyakarta: Penerbit Elmatera, 2017.

Hadi, Cholichul dan Fattah Hanurawan. Psikologi Industri dan Organisasi. Surabaya: Zifatama Jawara, 2018.

Hasibuan, Malayu S.P.. Manajemen Sumber Daya Manusia. Jakarta: PT Bumi Aksara, 2010.

Kadarisman, M.. Manajemen Kompensasi. Jakarta: PT. Rajagrafindo Persada, 2012.

Kristiani, Desi dan Ria Lestari Pangastuti. Kiat-kiat Merangsang Kinerja Karyawan Bagian Produksi. Surabaya: Media Sahabat Cendekia, 2019.

Margiati, Lulus. "Stres Kerja: Latarbetakang Penyebab dan Alternatif Pemecahannya", Masyarakat, Kebudayaan dan Politik, Th XII, No 3, 1999.

Marnisah, Luis. Hubungan Industrial dan Kompensasi. Yogyakarta: Deepublish, 2012.

Mohtar, Imam. Hubungan antara Motivasi Kerja dan Pengalaman Kerja dengan Kinerja Guru Madrasah. Surabaya: Uwais Inspirasi Indonesia, 2019.

Muhammad, Fadel. Reinventing Local Goverment. Jakarta: Kompas Gramedia, 2008.

Pianda, Didi. Kinerja Guru. Sukabumi: CV Jejak, 2018.

Rahim, Abdul, Saiyid Syech, dan Muhammad Zahari, MS, "Pengaruh Lingkungan Kerja dan Kompetensi terhadap Motivasi Kerja serta Dampaknya terhadap Kinerja Pegawai pada Dinas Pendidikan Kabupaten Tanjung Jabung Timur", J-MAS, Vol.2 No.2, 2017.

Sulaksono, Hari. Budaya Organisasi dan Kinerja. Yogyakarta: Deepublish, 2015.

Sutrisno, Edy. Manajeme Sumber Daya Manusia. Jakarta: Kencana, 2017.

Vanchapo, Antonius Rino. Beban Kerja dan Stres Kerja. Pasuruan: Penerbit Qiara Media, 2019.

Muhammad Reza Dimyanti, "Analisis Pengaruh Kerja terhadap Kinerja Pegawai dengan Komitmen Organisasial Sebagai Variabel Pemediasi", Jurnal Bisnis Strategi, Vol. 20, No. 2, (2011)

Nazaruddin Malik, Dinamika Pasar Tenaga Kerja, (Surabaya: UMM Press,2016),

Ngatemin dan Wanti Arumwanti, "Pengaruh Kompetensi dan Kompensasi terhadap Motivasi Kerja Karyawan Hotel di Kabupaten Karo Provinsi Sumatera Utara" Jurnal Riset Akuntansi Dan Bisnis, Vol. 12, No. 2 (2012)

Rismawati dan Mattalata, Evaluasi Kinerja, (Makassar: Media Perkasa, 2018)

Sari Permata Dewi, "Pengaruh Pengendalian Internal dan Gaya Kepemimpinan 
Terhadap Kinerja Karyawan SPBU Yogyakarta,"Jurnal Nominal, Vol. 1, No. 1 (2012)

Sugiyono, Statistika Untuk Penelitian, (Bandung: Alfabeta, 2015)

Supardi, Metodologi Peelitian Ekonomi \&Bisnis, (Yogyakarta: UII Press, 2005)

Syaiful F. Prihadi, Assessment Centre, (Jakarta: PT Gramedia Pustaka Utama, 2004),

Timbul Sinaga dan Mutiara Sinambela, "Pengaruh Stres Kerja terhadap Motivasi dan Kinerja Auditor pada Kantor Akuntan Publik di Kota Medan," Jurnal Akuntansi, Volume XVII, No. 01, (2013)

Toto Syatori dan Nanang Ghozali, Metode Penelitian Kuantitatif, (Bandung :Pustaka Setia, 2012)

Yoyo Sudaryo, Agus Ariwibowo, dan Nunung Ayu Sofiati, Manajemen Sumber Daya Manusia, (Yogyakarta: Penerbit Andi, 2018), 